\title{
Police Powers, Indirect Expropriation in International Investment Law, and Article $3 I(3)(c)$ of the VCLT: A Critique of Philip Morris $v$. Uruguay
}

\author{
Prabhash RANJAN* \\ South Asian University, India \\ pranjanI278@gmail.com
}

\begin{abstract}
Given the global contestation against BITs and ISDS, the outcome of the Philip Morris v. Uruguay case upholding Uruguay's right to regulate for public health is important for the international investment law community. However, it is not just the outcome of a case but also the quality of legal reasoning that is significant in building the legitimacy of the ISDS system. This paper focuses on the reasoning adopted by the tribunal in deciding whether Uruguay's regulatory measures resulted in the expropriation of Philip Morris's investment. The paper critiques the tribunal's use of Article $3 \mathrm{I}(3)(\mathrm{c})$ of the Vienna Convention on the Law of Treaties to invoke the police powers rule in interpreting the expropriation provision of the Switzerland-Uruguay BIT. The tribunal's reasoning was internally inconsistent and based on abuse of arbitral precedents. Clarity in legal reasoning by ISDS tribunals is imperative to boost the legitimacy of the ISDS system for all stakeholders.
\end{abstract}

There has been a steady increase in the number of bilateral investment treaties (BITstreaties between two countries aimed at protecting investments made by investors of both countries $^{\mathrm{I}}$ ) across the world-from 500 in the I990s to more than 3,324 by the end of 20I6. ${ }^{2}$ A BIT allows a foreign investor to directly bring a claim against a host state using the investor-state dispute settlement [ISDS], if the latter has taken a measure that allegedly

\footnotetext{
* Assistant Professor at the Faculty of Legal Studies, South Asian University [SAU], New Delhi, India. The author is extremely grateful to the anonymous reviewers of the Journal for their very helpful comments. The author also thanks Santosh Anand and Samarth Trigunayat of SAU for their help in writing the paper.

I. For a general discussion on BITs, see Rudolf DOLZER and Christopher SCHREUER, Principles of International Investment Law, 2nd ed. (Oxford: Oxford University Press, 2012); Jeswald W. SALACUSE, The Law of Investment Treaties, 2nd ed. (New York: Oxford University Press, 2015).

2. This includes 2,957 stand-alone investment treaties and 367 Treaties with Investment Provisions [TIPs] or investment chapters in FTAs; United Nations Conference on Trade and Development, "World Investment Report 20I7: Investment and the Digital Economy" (7 June 20I7), online: UNCTAD < http:// unctad.org/en/PublicationsLibrary/wir20 I7_en.pdf > .
} 
violates the BIT. ${ }^{3}$ The increasing mass of BITs has led to a significant increase in investorstate disputes in international investment law-from a negligible number in the early I990s, the total number of known treaty-based ISDS cases has risen to 767 as of I January 20I $7 .^{4}$ Foreign investors have used the ISDS provisions in BITs to challenge a wide range of state regulatory measures such as environmental measures, ${ }^{5}$ and monetary ${ }^{6}$ and taxation ${ }^{7}$ measures, as well as public health protection measures. ${ }^{8}$

Adjudication of disputes on potential breaches of BITs covering a wide breadth of sovereign regulatory measures by ISDS tribunals has triggered a debate on whether BITs are encroaching upon a host state's right to regulate. ${ }^{9}$ It has also triggered a backlash against BITs and ISDS, as evident from some states walking out of the system by denouncing the International Centre for the Settlement of Investment Disputes [ICSID] Convention ${ }^{\mathrm{IO}}$ (that provides for the ISDS mechanism). ${ }^{\text {II }}$ Additionally, some countries have terminated their BITs. ${ }^{\mathrm{I} 2}$

3. Salacuse, supra note I at 393 .

4. See United Nations Conference on Trade and Development, "Investment Dispute Settlement Navigator" (I January 20I7), online: UNCTAD < http://investmentpolicyhub.unctad.org/ISDS > .

5. Metalclad Corporation v. The United Mexican States, ICSID Case No. ARB(AF)/97/I, Award (30 August 2000) [Metalclad]; Methanex Corporation v. United States of America, NAFTA-UNCITRAL, Award (3 August 2005) [Methanex].

6. CMS Gas Transmission Company v. The Republic of Argentina, ICISD Case No. ARB/or/8, Award (I 2 May 2005), [CMS Award]; Enron Corporation and Ponderosa Assets, L.P. v. Argentine Republic, ICSID Case No. ARB/or/3, Award (22 May 2007) [Enron]; LG\&E Energy Corporation $v$. The Argentine Republic, ICISD Case No. ARB/o2/I, Award (25 July 2007) [LG\&.E Award]; Continental Casualty Company $v$. The Argentine Republic, ICSID Case No. ARB/o3/9, Award (5 September 2008).

7. Occidental Exploration and Production Company v. The Republic of Ecuador, LCIA Case No. UN 3467 , Final Award (I July 2004) [Occidental]; EnCana Corporation v. Republic of Ecuador, LCIA Case No. $\mathrm{UN}_{348}$ I, Award (3 February 2006) [EnCana]; Marvin Roy Feldman Karpa v. United Mexican States, ICSID Case No. ARB(AF)/99/I, Award (I6 December 2002); Burlington Resources Inc. v. Republic of Ecuador, ICSID Case No. ARB/o8/5, Decision on Liability (I4 December 2012).

8. Philip Morris Asia Ltd. v. The Commonwealth of Australia, UNCITRAL, PCA Case No. 20I 2-I2, Award on Jurisdiction and Admissibility (I7 December 20I 5); Philip Morris Brands Sàrl, Philip Morris Products S.A. and Abal Hermanos S.A. v. Oriental Republic of Uruguay, ICSID Case No. ARB/Io/7 (8 July 2016) [Philip Morris v. Uruguay].

9. For a debate on BITs, ISDS, and the right to regulate of a host state, see Catharine TITI, The Right to Regulate in International Investment Law (Oxford: Hart Publishing, 20I4); Barnali CHOUDHURY, "Recapturing Public Power: Is Investment Arbitration's Engagement of the Public Interest Contributing to the Democratic Deficit?” (2008) 4I Vanderbilt Journal of Transnational Law 775; Stephan W. SCHILL, "Enhancing International Investment Law's Legitimacy: Conceptual and Methodological Foundations of a New Public Law Approach" (20II) 52 Virginia Journal of International Law 57.

Iо. Convention on the Settlement of Investment Disputes Between States and Nationals of Other States, I 8 March I965, 575 U.N.T.S. I 59, (entered into force I4 October I966) [ICSID].

II. Bolivia, Ecuador, and Venezuela have denounced the ICSID Convention in 2007, 2009, and 20I2, respectively_see Tania VOON and Andrew D. MITCHELL, "Denunciation, Termination and Survival: The Interplay of Treaty Law and International Investment Law" (20I6) 3I ICSID Review-Foreign Investment Law Journal 4I3.

I2. Bolivia has terminated ten out of a total of twenty-three of its BITs; Ecuador has terminated eleven out of a total of twenty-nine of its BITs; Indonesia has terminated twenty-six out of a total seventy-one of its BITs-see Antony CROCKETT, "Indonesia's Bilateral Investment Treaties: Between Generations?" (20I 5 ) 30 ICSID Review-Foreign Investment Law Journal 437. South Africa has terminated nine out of a total of forty-nine of its BITs, most of which are not yet in force-see Engela C. SCHLEMMER, "An Overview of South Africa's Bilateral Investment Treaties and Investment Policy" (20I6) 3I ICSID Review-Foreign Investment Law Journal I. India has terminated fifty-eight of its BITs, although it is important to keep in mind that India has not completely walked away from the BITs and ISDS system, but has instead altered its terms of engagement-see Prabhash RANJAN and Pushkar ANAND, "The 2016 
Proposals which aim to amend the existing ISDS system by either making it more transparent ${ }^{\mathrm{I} 3}$ or by bringing about other kinds of reforms, such as introducing an appellate mechanism ${ }^{\mathrm{I} 4}$ or even developing a world investment court system, have also been advanced. ${ }^{15}$ It has also been persuasively argued that the frictions between the international investment law regime with competing public interests can be attenuated using various tools such as interpretative techniques and the recalibration of investment treaties. ${ }^{16}$ Indeed, some countries have started recalibrating their investment treaties to reconcile investment protection with a host state's right to regulate, thus avoiding the extreme step of denouncing BITs. ${ }^{\mathrm{I} 7}$

Against this backdrop, the recent decision of an ISDS tribunal in Philip Morris Brands

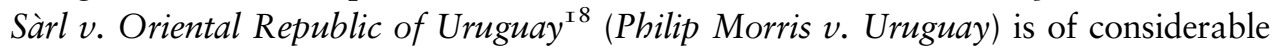
importance. ${ }^{19}$ This case, involving the competing interests of Philip Morris, a giant

Model Indian Bilateral Investment Treaty: A Critical Deconstruction” (2017) 38 Northwestern Journal of International Law and Business I.

I3. On the issue of reforms to the ISDS system, see Jean E. KALICKI and Anna JOUBIN-BRET, "Introduction" TDM Special Issue on "Reform of Investor-State Dispute Settlement: In Search of a Roadmap" (20I4) I I Transnational Dispute Management; and other contributions in the special issue, online: $<$ https://www.transnational-dispute-management.com/article.asp?key=2023 > . Also see United Nations Convention on Transparency in Treaty Based Investor State Arbitration (entered into force I 8 October 20I7), online: < https://www.uncitral.org/pdf/english/texts/arbitration/transparency-convention/Transparency-Convention-e.pdf $>$.

I4. Eun Young PARK, "Appellate Review in Investor State Arbitration" in Jean E. KALICKI and Anna JOUBIN-BRET, eds., Reshaping the Investor-State Dispute Settlement: Journeys for the Ist Century (Leiden: Brill Nijhoff and TDM-OGEMID, 2015) at 443-54.

I 5. See Free Trade Agreement between the European Union and The Socialist Republic of Vietnam, Chapter II (Investment), s. 3, art. I 5 (agreed text as of January 20I6); Also see Piero BERNARDINI, "Reforming Investor State Dispute Settlement: The Need to Balance Both Parties' Interests" (20I7) 32 ICSID ReviewForeign Investment Law Journal 38.

I6. Stephan SCHILL and Vladislav DJANIC, "Wherefore Art Thou? Towards a Public Interest-Based Justification of International Investment Law" (2018) 33 ICSID Review 29. The Investment chapter in the EU-Canada CETA is a good example of the recalibrating of investment treaties. Also see generally, Stephan SCHILL, "In Defense of International Investment Law" in M. BUNGENBERG, C. HERRMANN, M. KRAJEWSKI, and J.P. TERHECHTE, eds., European Yearbook of International Economic Law (Springer, 20I6), 309-4I; Charles N. BROWER and Sadie BLANCHARD, "What's in a Meme? The Truth about Investor-State Arbitration: Why It Need Not, and Must Not, Be Repossessed by States" (20I4) 52 Columbia Journal of Transnational Law 689.

I7. The US and Canadian Model BITs are examples of countries trying to define substantive provisions with greater precision so as to reconcile the interests of foreign investors and a host state's right to regulatesee 2012 U.S. Model BIT, online: https://ustr.gov/sites/default/files/BIT\% $\%$ otext $\% 20$ for $\% 20$ ACIEP\% 20Meeting.pdf [20I2 US Model BIT]; 2004 Canadian Model BIT, online: < http://www.italaw.com/ documents/Canadian2004-FIPA-Model-en.pdf >. Also see Caroline HENCKELS, "Protecting Regulatory Autonomy Through Greater Precision in Investment Treaties: The TPP, CETA, and TTIP" (20I6) I9 Journal of International Economic Law 27; Jonathan BONNITCHA, Lauge N. SKOVGAARD POULSEN, and Michael WAIBEL, The Political Economy of the Investment Treaty Regime (Oxford: Oxford University Press, 2017). Also see art. 8.9 of the Comprehensive Economic and Trade Agreement Between Canada and the European Union, 30 October, 2016, ch. 8 (Investment).

I 8. ICSID Case No. ARB/ıo/7, Award (8 July 20I6), online: http://icsidfiles.worldbank.org/icsid/ICSID BLOBS/OnlineAwards/Ciooo/DC90 I 2_En.pdf.

I 9. Recent International Decision, "Philip Morris Brands Sàrl v. Oriental Republic of Uruguay" (20I7) I30 Harvard Law Review 1986; Tania VOON and Andrew MITCHELL, "Philip Morris v Tobacco Control: Two Wins for Public Health, but Uncertainty Remains” (20I6) I 82 Columbia FDI Perspectives, online: < http://ccsi.columbia. edu/files/20I3/Io/No-I82-Voon-and-Mitchell-FINAL.pdf > ; Kate MITCHELL, "Philip Morris v Uruguay: An Affirmation of 'Police Powers' and 'Regulatory Power in the Public Interest'" (2016) European Journal of International Law, online: EJIL: Talk < https:/www.ejiltalk.org/philip-morris-v-uruguay-an-affirmation-of-police-powers-and-regulatory-power-in-the-public-interest-in-international-investment-law/>; Yannick RADI, 
tobacco company, and the public health interests of Uruguay, came to be seen as a litmus test to determine whether BITs and ISDS unduly encroach upon a host state's right to regulate. Philip Morris challenged Uruguay's two public health measures aimed at restricting the marketing of tobacco products. ${ }^{20}$ The two public health measures are: (I) the "Single Presentation Requirement" [SPR], which requires that cigarette brands sell only under a single package or variant, and (2) the " $80 / 80$ Regulation", which mandates that the health warnings on cigarette packages increase from fifty percent to eighty percent of the surface of the packages, leaving only twenty percent of the space on the packages for display of trademarks, logos, and other information. ${ }^{2 \mathrm{I}}$ Philip Morris challenged these regulations as breaching Uruguay's obligations under the SwitzerlandUruguay BIT. ${ }^{22}$ Specifically, Philip Morris argued that the two measures adopted by Uruguay violated the following Articles of the Switzerland-Uruguay BIT: Article $3(\mathrm{I})$ (impairment of use and enjoyment of investments), Article $3(2)$ (fair and equitable treatment [FET] and denial of justice), Article 5 (expropriation), and Article I I (observance of commitments entered into with respect to investments of investors). ${ }^{23}$ The tribunal, by a majority, upheld the legality of the two Uruguayan regulatory measures ${ }^{24}$ and dismissed Philip Morris's claims. ${ }^{25}$ The tribunal found that the two Uruguayan regulatory measures neither violated the FET provision nor the provision on expropriation in Article 5 of the Switzerland-Uruguay BIT.

The outcome of this case is extremely significant, not just for Uruguay, but also for the international investment law community at large. The tribunal's decision of upholding Uruguay's right to adopt measures for the protection of public health as consistent with the BIT could be seen as a measure to shore up the eroding confidence of countries in BITs and ISDS. Defenders of the regime would use this case to argue that the fear of BITs and ISDS unduly encroaching upon a host state's regulatory autonomy are exaggerated. Arguably, if the tribunal had ruled in favour of Philip Morris, it might have given political impetus to many states to withdraw from investment treaties. However, the fact that one of the arbitrators dissented in part and held that the SPR violated the FET and denial of justice provision in the Switzerland-Uruguay BIT ${ }^{26}$

"Philip Morris v Uruguay-Regulatory Measures in International Investment Law: To be or Not To Be Compensated?” (20I 8) ICSID Review-Foreign Investment Law Journal, online: < https://academic.oup. com/icsidreview/advance-article/doi/Io.I093/icsidreview/sixo3 I/4832553>.

20. Philip Morris v. Uruguay, supra note 8, paras. 9-II. In this case, the claimants include Philip Morris Brand Sàrl (Switzerland) (PMB), Philip Morris Products S.A. (Switzerland) (PMP), and Abal Hermanos S.A. (Abal), jointly referred to as "Philip Morris".

2I. Ibid.

22. Ibid., para. I2.

23. Ibid.

24. Arbitrator Gary Born wrote a concurring and a dissenting opinion, Philip Morris v. Uruguay, Award, Annex B (Concurring and Dissenting Opinion) with regard to two aspects of the tribunal's ruling on the fair and equitable treatment [FET] provision. First, the contradictory decisions rendered by Uruguay's Supreme Court and the administrative law court constituted a denial of justice (paras. 6-9). Second, Uruguay's SPR was “arbitrary and unreasonable” (para. 82).

25. Philip Morris $v$. Uruguay, supra note 8, para. 590.

26. Philip Morris v. Uruguay, Award, Annex B (Concurring and Dissenting Opinion), supra note 24, para. I96. 
arguably reveals the continuing uncertainties in defending sovereign health-related regulatory measures before ISDS tribunals. ${ }^{27}$

\section{PURPOSE AND SCOPE OF THE PAPER}

Generally speaking, the acceptability of the outcome of an ISDS case is considered more important than the rigour of the tribunal's reasoning. ${ }^{28}$ This paper, while recognizing that the outcome of the Philip Morris award is important, focuses critically on the reasoning adopted by the tribunal. The purpose is to examine the clarity and rigour in the tribunal's reasoning because the quality of arbitral reasoning, not just the outcome, plays an important role in building the legitimacy of the ISDS system. ${ }^{29}$ ISDS awards that are not judiciously and thoroughly reasoned lead to incoherent case-law, ${ }^{3 \circ}$ and augment the anxiety and resentment of states towards international arbitration. ${ }^{3 \mathrm{I}} \mathrm{Such}$ awards dampen the effectiveness of the system because both states and foreign investors are not able to mould their conduct in accordance with the standards articulated by the tribunals. ${ }^{32}$ Ortino has identified three types of egregious failures in the reasoning of the ISDS tribunals: misuse of precedent, lack of internal consistency, and minimalism. ${ }^{33}$

Given the significance of clarity and rigour in legal reasoning, this paper critically examines the reasoning of the Philip Morris tribunal in dealing with the question of whether Uruguay's regulatory measures resulted in the expropriation of Philip Morris's investment. Specifically, the paper discusses how the tribunal used Article 3 I (3)(c) of the Vienna Convention on the Law of Treaties [VCLT] to invoke the police powers rule in interpreting the expropriation provision of the Switzerland-Uruguay BIT under which the dispute arose. Given the paucity of space, the paper does not discuss other important aspects of the award, such as the interpretation of the FET provision.

There are two important reasons to focus on the tribunal's reasoning and interpretation of the expropriation provision. First, one of the most common grounds for challenging a host state's regulatory measures is that the measures breach the

27. Voon and Mitchell, supra note I9.

28. Jürgen KURTZ, “Adjudging the Exceptional at International Investment Law: Security, Public Order and Financial Crisis” (2010) 59 International and Comparative Law Quarterly 325 at 349.

29. See Jürgen KURTZ, "Building Legitimacy Through Interpretation in Investor-State Arbitration" in Zachary DOUGLAS, Joost PAUWELYN, and Jorge E. VINUALES, eds., The Foundations of International Investment Law (Oxford: Oxford University Press, 20I4), 257.

30. See Federico ORTINO, "Legal Reasoning of International Investment Tribunals: A Typology of Egregious Failures" (2OI2) 3 Journal of International Dispute Settlement 3 I at 34. A very good example of a lack of clarity in legal reasoning leading to incoherent and inconsistent decisions is how many ISDS tribunals interpreted art. XI of the US-Argentina BIT. All these tribunals dealt with the same legal provision, yet reached different and inconsistent conclusions due to unclear reasoning-see Kurtz supra note 28. See supra note 6 for the list of these cases.

3 I. Toby LANDAU, "Reasons for Reasons: The Tribunal's Duty in Investor-State Arbitration" (2009) I4 ICCA Congress Series I87. Also see Pierre LALIVE, "On the Reasoning of International Arbitral Awards" (2010) I Journal of International Dispute Settlement 55 at 57.

32. Ortino supra note 30 at $3 \mathrm{I}$.

33. Ibid., 34 . 
expropriation provision in the BIT. ${ }^{34}$ As direct expropriations-state actions which deprive investors of legal title ${ }^{35}$ - have become rare, ${ }^{36}$ the focus has shifted to determining what constitutes indirect expropriation-deprivation of the substantial benefits flowing from the investment without any formal "taking" of the property. ${ }^{37}$ Determining what constitutes indirect expropriation is not easy. ISDS tribunals have developed different tests to do so, such as the sole effects test where the focus is only on the severity of the effect of the regulatory measure on foreign investment. ${ }^{38}$ According to this test, measures that do not constitute direct expropriation may nevertheless constitute indirect expropriation if the effect of the regulatory measure causes a substantial deprivation of foreign investment. ${ }^{39}$ In addition, some tribunals have developed what is described as the police powers test, borrowed from customary international law [CIL], ${ }^{4 \circ}$ where state measures that are prima facie lawful exercises of the government's powers (such as adopting a measure pursuing a legitimate public welfare objective) may affect foreign interests considerably without amounting to expropriation. ${ }^{4 \mathrm{I}}$ Apart from these two tests, there is a third test: proportionality analysis, which requires balancing the public purpose behind the regulatory measure with the effect that the measure has on foreign investment. ${ }^{42}$

34. Foreign investors have challenged a large range of regulatory measures pertaining to taxation, environmental protection, etc. as expropriation under different BITs. See Metalclad, supra note 5; Methanex, supra note 5; Biwater Gauff (Tanzania) Ltd. $v$. United Republic of Tanzania, ICSID Case No. ARB/05/22 (ICSID Arb. Trib. 2008); Occidental, supra note 7; EnCana, supra note 7.

35. Salacuse, supra note I at 322.

36. Dolzer and Schreuer, supra note I at IOI.

37. Ibid., at 92; Salacuse, supra note I at 297; Starrett Housing Corporation v. Islamic Republic of Iran (1983) 4 Iran-US CTR I22, I 54. Also see Tippetts, Abbett, McCarthy, Stratton and TAMS-AFFA Consulting Engineers of Iran $v$. Islamic Republic of Iran (I984) 6 Iran-US CTR 2 I9, 225.

38. See Ben MOSTAFA, "The Sole Effects Doctrine, Police Powers and Indirect Expropriation under International Law" (2008) I 5 Australian Journal of International Law 267.

39. Pope and Talbot Inc. v. The Government of Canada, Ad hoc Tribunal (UNCITRAL), Interim Award, (26 June 2000), para. 96; PSEG v. Turkey, ICSID Case No ARB/o2/5, Award (I9 January 2007), paras. 2788० [PSEG]; CMS Award, supra note 6, para. 262.

40. See Andrew NEWCOMBE and Lluís PARADELL, Law and Practice of Investment Treaties: Standards of Treatment (Alphen Aan Den Rijn: Kluwer Law International, 2009) at 358-62.

4I. See Jorge E VINUALES, "Sovereignty in Foreign Investment Law" in Zachary DOUGLAS, Joost PAUWELYN, and Jorge E. VINUALES, eds., The Foundations of International Investment Law (Cambridge: Cambridge University Press: 20I4), 3 I7-62; Ian BROWNLIE, Principles of Public International Law, 7th ed. (New York: Oxford University Press, 2008) at 532; George C. CHRISTIE, "What Constitutes a Taking of Property under International Law?" ( I 962) 33 British YearBook of International Law at 335, 338; J Martin WAGNER, "International Investment, Expropriation and Environmental Protection" (I999) 29 Golden Gate University Law Review at 465, 517-19; Alain PELLET, "Police Powers or the State's Right to Regulate" in M. KINNEAR, ed., Building International Investment Law: The First 50 Years of ICSID (The Hague: Kluwer Law International, 20I 5) 447-62; Methanex, supra note 5, Part IV, Ch D, 4, para. 7; Saluka Investments B.V. (The Netherlands) $v$. The Czech Republic, UNCITRAL, Partial Award (I7 March 2006); El Paso Energy International Company v. The Argentine Republic, ICSID Case No. ARB/o3/I 5 , Award, (3 I October 20I I) [El Paso].

42. Alec Stone SWEET, “Investor-State Arbitration: Proportionality's New Frontier" (2010) 4 Law and Ethics of Human Rights at 47; Caroline HENCKELS, "Indirect Expropriation and the Right to Regulate: Revisiting Proportionality Analysis and the Standard of Review in Investor-State Arbitration" (20I2) I 5 Journal of International Economic Law at 223-55; Tecnicas Medioambientales Tecmed, S.A. $v$. The United Mexican States, ICSID Case No. ARB(AF)/oo/2 (Award) (29 May 2003) [Tecmed Award]; LGóE Award, supra note 6, para. I95; Azurix Corp. v. The Argentine Republic, ICSID Case No. ARB/ oI/I2, Award (I4 July 2006), para. 3I 2 [Azurix]; El Paso, supra note 4I, para. 24I; Joseph Charles Lemire v. Ukraine, ICSID Case No. ARB/o6/I8, Decision on Jurisdiction and Liability, para. 285 (I4 January 2010). 
The Philip Morris tribunal focused on both the sole effect (or substantial deprivation) test and the police powers test to determine whether foreign investment had been indirectly expropriated. As the paper will discuss, the use of both tests muddies the water and does not bring much clarity to the question of what constitutes indirect expropriation. Also, the use of the police powers test raises critical questions regarding the definition of police powers and its application, which has implications far beyond the current case. ${ }^{43}$

The second important reason is the tribunal's use of Article $3 \mathrm{I}(3)(\mathrm{c})$ of the VCLT to invoke the police powers rule in interpreting the expropriation provision of the BIT. Article $3 \mathrm{I}(3)$ (c) of the VCLT provides: "There shall be taken into account, together with the context: (c) any relevant rules of international law applicable in the relations between the parties." 44 As Simma and Kill argue, tribunals routinely refer to international law rules that derive their normative legitimacy from sources outside the treaty which is the subject matter of interpretation. ${ }^{45}$ Article $3 \mathrm{I}(3)(\mathrm{c})$, which has attracted considerable attention, ${ }^{46}$ reflects the proposition that no treaty originates outside the international legal system and that this system will continue to be relevant for the purposes of interpreting an international treaty. ${ }^{47}$ Article $3 \mathrm{I}(3)(\mathrm{c})$ has been widely hailed as an instrument for bringing about the systemic integration of international law. ${ }^{48}$ ISDS arbitral tribunals have started referring to Article $3 \mathrm{I}$ (3)(c) of the VCLT as a tool for interpreting the investment treaty in question. ${ }^{49}$ For the international investment law community, an important question is how well the tribunals

43. Newcombe and Paradell, supra note 40 at 358-62; Prabhash RANJAN and Pushkar ANAND, "Determination of Indirect Expropriation and Doctrine of Police Power in International Investment Law" in Leila CHOUKROUNE, ed., Judging the State in International Trade and Investment Law (Singapore: Springer, 2016), I27-5I.

44. Vienna Convention on the Law of Treaties, 23 May I969, I 55 U.N.T.S. 33 I, 8 I.L.M. 679 (entered into force 27 January I980).

45. Bruno SIMMA and Theodore KILL, "Harmonising Investment Protection and International Human Rights: First Steps Towards a Methodology" in Christina BINDER, Ursula KRIEBAUM, August REINISCH, and Stephan WITTICH, eds., International Investment Law for the 2 Ist Century: Essays in Honour of Christoph Schreuer (New York: Oxford University Press, 2009), 679 at 68I-2. Also see J Romesh WEERAMANTRY, Treaty Interpretation in Investment Arbitration (Oxford/New York: Oxford University Press, 20I2).

46. Fragmentation of International Law: Difficulties Arising from the Diversification and Expansion of International Law, Report of the Study Group of the International Law Commission [ILC], finalized by Martti KOSKENNIEMI, UN Doc.A/CN.4/L/682 (2006) [ILC Anti-Fragmentation Report]; Joost PAUWELYN, Conflict of Norms in Public International Law: How WTO Law Relates to other Rules of International Law (Cambridge: Cambridge University Press, 2004) at 253-70; Vassilis P. TZEVELEKOS, "The Use of Article $3 \mathrm{I}(3)(\mathrm{C})$ of the VCLT in the Case Law of the ECtHR: An Effective Anti-Fragmentation Tool or a Selective Loophole for the Reinforcement of Human Rights Teleology?” (20I0) 3 I Michigan Journal of International Law 62I; Panos MERKOURIS, Article 3I(3)(c) VCLT and the Principle of Systemic Integration (Leiden: Brill Nijhoff, 20I 5 ).

47. For a full discussion on art. $3 \mathrm{I}(3)(\mathrm{c})$ of the VCLT, see Richard K. GARDINER, Treaty Interpretation (New York: Oxford University Press, 2008) 256-8I.

48. See ILC Anti-Fragmentation Report, supra note 46, paras. 4IO-80; Campbell MCLACHLAN, "The Principle of Systemic Integration and Article $3 \mathrm{I}(3)(\mathrm{C})$ of the Vienna Convention" (2005) 54 International and Comparative Law Quarterly 279; Tzevelekos, supra note 46 . For a contrary view on the so-called "anti-fragmentation" function of art. 3 I (3)(c), see Mélanie SAMSON, "High Hopes, Scant Resources: A Word of Skepticism about the Anti-fragmentation Function of Article 3 I (3)(c) of the Vienna Convention on the Law of Treaties" (20II) 24 Leiden Journal of International Law 70I.

49. See Saluka v. Czech Republic, supra note 4I; Ioannis Kardassopoulos v. The Republic of Georgia, ICSID Case No. ARB/05/I 8 (Decision on Jurisdiction) (6 July 2007), at para. 270; Veteran Petroleum Ltd (Cyprus) v. The Russian Federation, UNCITRAL (Interim Award) (30 November 2009), at para. 309; El Paso, supra note 4I, paras. 60I-2. 
have reasoned the use of Article $3 \mathrm{I}(3)(\mathrm{c})$ when referring to treaty or customary norms outside the investment treaty. This question is extremely pertinent because the ISDS system's engagement with external legal norms could have implications for the legitimacy of the system. ${ }^{50}$

It is important to bear in mind that Article $3 \mathrm{I}(3)(\mathrm{c})$ of the VCLT is not the only gateway for bringing extraneous rules, like a customary rule of police powers, into the interpretation of investment treaties. If a treaty term has a meaning recognized in customary law, the customary law could arguably be incorporated as "ordinary" meaning under Article $3 \mathrm{I}(\mathrm{I})$, or as "special" meaning under Article $3 \mathrm{I}(4)$ of the VCLT. ${ }^{5 \mathrm{I}}$ However, since the Philip Morris tribunal focused only on Article $3 \mathrm{I}(3)$ (c) to deal with extraneous rules, this paper restricts its analysis to Article $3 \mathrm{I}(3)$ (c). While the focus of this paper is the issues of Article $3 \mathrm{I}(3)(\mathrm{c})$ and the police powers rule through the prism of the Philip Morris case, the issues it discusses have wider implications, and are thus of interest to the international investment law community as a whole.

The Philip Morris tribunal's reasoning on indirect expropriation is at two levels: first, whether the regulatory measures, i.e. the SPR and 8o/80 Regulation, deprived Abal (Philip Morris Brand Sarl owned Ioo percent of Abal-an entity constituted under the laws of Uruguay $^{52}$ ) of the value of its business or caused a "substantial deprivation" of the value, use, or enjoyment of its investment; and second, whether the challenged measures were a valid exercise of Uruguay's police powers, which would defeat the expropriation claim under Article 5(I). Therefore, Section II of this paper deals with the tribunal's application of the substantial deprivation test. In Section III, the paper deals with the tribunal's application of the police powers test using Article $3 \mathrm{I}(3)$ (c) of the VCLT. Section IV concludes by discussing what the Philip Morris tribunal should have done and by raising larger conceptual issues on the relationship between the police powers rule and determination of indirect expropriation.

\section{THE TEST OF SUBSTANTIAL DEPRIVATION TO DETERMINE WHAT CONSTITUTES INDIRECT EXPROPRIATION}

In this section, we discuss the tribunal's focus on the substantial deprivation test to determine whether expropriation had taken place. The tribunal's task was to interpret Article 5(I) of the Switzerland-Uruguay BIT, which states:

Neither of the Contracting Parties shall take, either directly or indirectly, measures of expropriation, nationalization or any other measure having the same nature or the same effect against investments belonging to investors of the other Contracting Party, unless the measures are taken for the public benefit as established by law, on a non-discriminatory basis, and under due process of law, and provided that provisions be made for effective and adequate compensation. The amount of compensation, interest included, shall be settled in the currency of the country of origin of the investment and paid without delay to the person entitled thereto.

\footnotetext{
50. Kurtz, supra note 29 at 280.

5I. Martins PAPARINSKIS, “Investment Treaty Interpretation and Customary Investment Law: Preliminary Remarks" in Chester BROWN and Kate MILES, eds., Evolution in Investment Treaty Law and Arbitration (Cambridge: Cambridge University Press, 20II), 65 at 78.

52. Philip Morris v. Uruguay, supra note 8, paras. 2-5.
} 
Thus, Article 5(I) of the BIT clearly prohibits countries from adopting expropriatory measures, either directly or indirectly, unless the measures are taken for public benefit on a non-discriminatory basis, following due process, and provisions are made for effective and adequate compensation. Since this case involved determining what constitutes indirect expropriation, the important words in Article 5(I) are "any other measure having the same nature or the same effect against investments".

The tribunal began its analysis in paragraph I9I by recognizing that the claim relates to indirect expropriation. The question that the tribunal asked itself was to determine the threshold for finding indirect expropriation. ${ }^{53}$ The tribunal started answering this question in paragraph 192 at two levels. First, to determine what constitutes indirect expropriation, the tribunal recognized the central role of the "effect" of the regulatory measure on investment. In other words, the tribunal recognized the "sole effects" doctrine ${ }^{54}$ to determine what constitutes indirect expropriation, whereby the crucial factor in determining whether an indirect expropriation has occurred is solely the effect of the governmental measure on the property. Thus, the purpose behind the regulatory measure is irrelevant under the sole effects test. The justification which many ISDS tribunals have offered for relying on the sole effects test is textual, i.e. the expropriation provision in the BIT contains only the word "effect", as is the case with Article $5(\mathrm{I})$ of the Switzerland-Uruguay BIT. For example, in AWG $v$. Argentina, ${ }^{55}$ where the expropriation provision in the UK-Argentina BIT contains the phrase "subjected to measures having effect equivalent to nationalization or expropriation", the tribunal held that specific reference to "effects" in the BIT "affirms the importance of evaluating 'effects' of the measure on the investment in determining whether an expropriation has taken place"..$^{6}$

Second, in paragraph I92, the tribunal recognized that the focus on the "effect" of the regulatory measure on foreign investment to determine what constitutes indirect expropriation fails to answer the key question: i.e. how severe should the effect be? The tribunal stated that "in order to be considered an indirect expropriation, the government's measures interference with the investor's rights must have a major adverse impact on the claimant's investments". ${ }^{57}$ The tribunal further clarified that, for regulatory measures to have a major adverse impact, the regulatory measures should lead to "substantial deprivation" of the value, use, or enjoyment of the claimant's investment. ${ }^{8}$ The effect can certainly be more than substantial deprivation, such as cases

53. Ibid., para I9I.

54. Rudolf DOLZER and Felix BLOCH, "Indirect Expropriations: Conceptual Realignments?" (2003) 5 International Law Forum I 55.

55. AWG Group Ltd v. The Argentine Republic, ICSID Case No. ARB/०3/I9, 30 July 20 Io.

56. Ibid., para. I33. Also see EnCana, supra note 7, paras. 173-8; Tippetts, Abbett, McCarthy Stratton v. TAMS AFFA Consulting Engineers of Iran, (1984), 6 Iran-US CTR 219 at 225-6; Starrett Housing Corp v. Iran, 4 Iran-US CTR I 22; Enron v. Argentina, supra note 6, para. 244; Metalclad, supra note 5, para. I03; Compania de Aguas del Aconquija S.A. and Vivendi Universal S.A. $v$. Argentine Republic, ICSID Case No ARB/97/3, Award, 20 August 2007, para. 7.5.20; Spyridon Roussalis v. Romania, ICSID Case No. ARB/o6/I, Award, 7 December 20I I, paras. 328, 330; Mr. Patrick Mitchell v. Democratic Republic of Congo ICSID Case No ARB/99/7, (Annulment Proceedings) para. 53 for the "sole effect" doctrine.

57. Philip Morris v. Uruguay, supra note 8, para. 192

58. Ibid. Indeed, the tribunal in Pope and Talbot v. Canada held that "under international law, expropriation requires a 'substantial deprivation"'; see Pope and Talbot v. Canada, supra note 39, para. 96. Also see 
where the deprivation is complete or total. For example, the tribunal in Total SA $v$. Argentina ${ }^{59}$ held that, under international law, those measures that do not constitute direct expropriation may nevertheless result in indirect expropriation "if an effective deprivation of the investment is thereby caused". ${ }^{60}$ Furthermore, the Philip Morris tribunal said that substantial deprivation would be determined by taking into account the "intensity" and "duration" of the economic deprivation suffered by the investor. ${ }^{6 I}$

On the basis of these principles, and having examined the claims of the investor, the tribunal held that the regulatory measures adopted by Uruguay did not result in substantial deprivation of Abal's investment. ${ }^{62}$ The tribunal held that, since sufficient value of the investment remained after the implementation of the challenged regulatory measures, the impugned measures did not amount to indirect expropriation. ${ }^{63}$ The tribunal found that, despite the adoption of the regulatory measures by Uruguay, Abal's profits had increased, though the profits would have increased to a greater extent if the impugned regulations had not been adopted. ${ }^{64}$ Consequently, the tribunal concluded that there was no indirect expropriation of Abal's investment.

Up to this point, it is difficult to find fault with the reasoning of the tribunal. The tribunal carefully interpreted Article 5(I) and correctly applied the law to the facts at hand - an adverse economic effect on foreign investment such as deteriorating profits, or the incurring of losses, short of total or at least substantial deprivation, shall not amount to indirect expropriation. ${ }^{65}$ This interpretation gives ample space to host states to exercise their regulatory powers without worrying about foreign investors challenging such actions as expropriations, unless the high threshold of substantial deprivation is breached.

\section{ARTICLE $3 \mathrm{I}(3)(\mathrm{C})$ OF VCLT AND POLICE POWERS}

The finding that Uruguay did not indirectly expropriate foreign investment obviated the need to deal with the issue of expropriation any further. The tribunal itself tacitly accepted this in paragraph 287: "the tribunal's analysis [of the indirect expropriation claim] might end here". ${ }^{66}$ However, the tribunal did not stop there, and went on to offer an "additional" reason to support its conclusion. The tribunal held that the SPR

PSEG, supra note 39, paras. 278-80; CMS Award, supra note 6, Decision on Liability, para. 262. LG\&E $v$. Argentina, para. I94; Sempra v. Argentina, paras. 284-5; BG Group v. Argentina, UNCITRAL, 24 December 2007, at paras. 258-66; Enron v. Argentina, supra note 6, para. 245. AWG Group Ltd. v. The Argentine Republic, UNCITRAL, Decision on Liability, 30 July 2010, at para. I34; Corn Products International. Inc. $v$. United Mexican States, ICSID Case No ARB (AF)/o4/I, (NAFTA), Decision on Responsibility, I 5 January 2008, at para. 9I.

59. Total S.A. $v$. The Argentine Republic, ICSID Case No ARB/O4/OI, Decision on Liability, 27 December 2010.

6o. Ibid., para. I95.

6I. Philip Morris $v$. Uruguay, supra note 8, para. I92.

62. Ibid., para. 284 .

63. Ibid., para. 286.

64. Ibid., paras. 284, 285. Also see LG 2 E v. Argentina, ICISD Case No ARB/o2/I, Decision on Liability, 3 October 2006, para. I9I.

65. Philip Morris v. Uruguay, supra note 8, para. 192.

66. Ibid., para. 287 . 
and $80 / 80$ Regulation adopted by Uruguay was a valid exercise of its police powers, "with the consequence of defeating the claim for expropriation under Article 5(I) of the BIT". ${ }^{67}$ The tribunal held that for this reason "also", the claim regarding indirect expropriation must be rejected. ${ }^{68}$ The usage of words like "additional" and "also" is curious. The use of these words suggests that, according to the tribunal, the defence of police powers always operates as an extra argument or reason to defeat the claim of indirect expropriation once it is established that the regulatory measures did not result in a "substantial deprivation" of foreign investment. But, what if the initial analysis had sufficed to show that the challenged regulatory measures led to a "substantial deprivation" of Abal's investment? If the police powers argument is an "additional" reason to defeat expropriation claims, it would be of no significance if regulatory measures did result in substantial deprivation of foreign investment.

This approach adopted by the Philip Morris tribunal somewhat mirrors the approach adopted in Chemtura v. Canada. ${ }^{69}$ The Chemtura tribunal, while examining whether the regulatory measure amounted to indirect expropriation, first considered whether the regulatory measures resulted in substantial deprivation of investment. ${ }^{70}$ Once the tribunal came to the conclusion that there was no "substantial deprivation", ${ }^{7 \mathrm{I}}$ it was said that "irrespective of contractual deprivations", the measures challenged were part of the state's police powers, and thus did not constitute expropriation. ${ }^{72}$

The tribunal in AWG $v$. Argentina also followed a similar route. As pointed out earlier, the tribunal first affirmed the importance of determining the "effect" of the regulatory measures on foreign investment and whether the regulatory measures had resulted in a "substantial deprivation" of foreign investment. ${ }^{73}$ It then held that, in evaluating a claim of expropriation, "it is important to recognize a State's legitimate right to regulate and to exercise its police power in the interests of public welfare and not to confuse measures of that nature with expropriation". ${ }^{74}$ Finally, the tribunal concluded that the measures adopted by Argentina were within the general police powers of the Argentine state, and that they did not constitute a permanent and substantial deprivation of foreign investment, and thus did not amount to indirect expropriation. ${ }^{75}$ The conclusion reached by the $A W G$ tribunal makes one wonder what the outcome would have been if the regulatory measures had led to a permanent and substantial deprivation of foreign investment. Would it have resulted in a finding of expropriation or would the application of the police powers rule mean a finding of no expropriation despite substantial deprivation? Be that as it may, we now turn to critically examine the Philip Morris tribunal's reasoning on the application of the police powers rule using Article $3 \mathrm{I}(3)$ (c) of the VCLT.

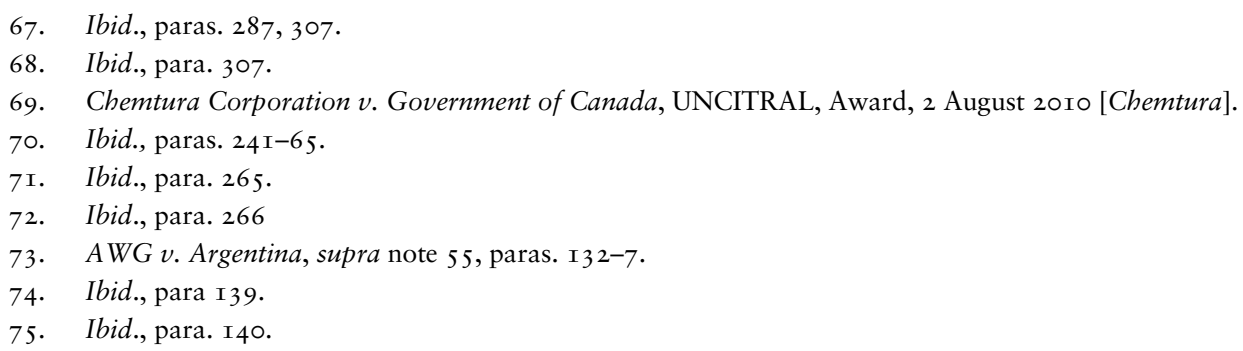




\section{A. How did the Tribunal Use Article $3 I(3)(c)$ ?}

The tribunal reasoned that Article 5(I) of the Switzerland-Uruguay BIT should be interpreted in accordance with Article $3 \mathrm{I}(3)$ (c) of the VCLT. The tribunal used Article $3 \mathrm{I}(3)(\mathrm{c})$ to incorporate the police powers rule in CIL to interpret Article $5(\mathrm{I})$ of the BIT.

The critical question is whether the tribunal used Article $3 \mathrm{I}(3)(\mathrm{c})$ correctly to interpret Article 5(I) of the Switzerland-Uruguay BIT. Before we look at how the tribunal used Article $3 \mathrm{I}(3)(\mathrm{c})$ of the VCLT, it will be useful to first have a quick look at the legal architecture of Article $3 \mathrm{I}(3)(\mathrm{c})$. As indicated before, according to the wording of Article $3 \mathrm{I}(3)(\mathrm{c})$, the treaty interpreter is under an obligation to take into account any relevant rules of international law that are applicable in the relations between the parties. Analytically speaking, the interpretative framework that Article $3 \mathrm{I}(3)(\mathrm{c})$ provides to the treaty interpreter comprises the following: ${ }^{76}$ first, one has to determine whether there is a "rule of international law"; 77 second, whether such a rule is "applicable in the relations between the parties" $7^{78}$ third, this applicable rule should also be "relevant"; $;^{79}$ and fourth, if a rule satisfies the three conditions mentioned above, it is admissible in the process of interpretation, ${ }^{8 \circ}$ though one still has to determine the weight that should be accorded to this admissible rule in the interpretation of the treaty norm. ${ }^{81}$

In paragraph 290, the tribunal referred to Article $3 \mathrm{I}(3)(\mathrm{c})$ and held that the provision mandates the tribunal to refer to rules of CIL. ${ }^{82}$ Hence, the tribunal referred to the police powers rule, which is part of CIL. ${ }^{83}$ The tribunal also held that protecting public health has "long been recognized as an essential manifestation of the State's police power". ${ }^{84}$ The tribunal, like some tribunals in the past ${ }^{{ }^{8}}$ located the authority for the police powers rule in the 196I Harvard Draft Convention on the International Responsibility of States for Injuries to Aliens ${ }^{86}$ specifically in Article ro(5), and in the Third Restatement of the Foreign Relations Law of the United States (US) 1987. ${ }^{87}$

76. See Paparinskis, supra note $5 \mathrm{I}$ at 73; Bruno SIMMA, "Foreign Investment Arbitration: A Place for Human Rights" (20 I I) 60 International and Comparative Law Quarterly 573 at 584-5; Simma and Kill, supra note 45 at 695-9; Gardiner, supra note 47 at 259-65.

77. Simma, supra note 76 at 585 .

78. Ibid.

79. Ibid.; Paparinskis, supra note $5 \mathrm{I}$ at 70-I.

80. Paparinskis, supra note $5 \mathrm{I}$; Kurtz, supra note 29 at $280-\mathrm{I}$.

8I. Paparinskis, supra note $5 \mathrm{I}$.

82. Philip Morris $v$. Uruguay, supra note 8 at para. 290.

83. Ibid., at paras. 29I, 292, 293, 294. Legal scholarship also recognizes the police powers rule as part of CIL - see Newcombe and Paradell, supra note 40 at 358; Vinuales, supra note 4I at 329, 344; Pellet, supra note $4 \mathrm{I}$ at 449 . A related issue could be whether the police powers rule is part of CIL or a general principle of law under art. $38(\mathrm{I})(\mathrm{c})$ of the ICJ Statute-see Catharine TITI, "Police Powers Doctrine and International Investment Law" in Filippo FONTANELLI, Andrea GATTINI, and Attila TANZI, eds., General Principles of Law and International Investment Arbitration (Brill, 201 8) 323, online: < https://ssrn.com/ abstract $=30504 \mathrm{I} 7>$.

84. Philip Morris v. Uruguay, supra note 8 at para. $29 \mathrm{I}$.

85. Saluka v. Czech Republic, supra note 4I at para. 256.

86. Louis B. SOHN and B.B. BAXTER, "Draft Convention on the International Responsibility of States for Injuries to Aliens” (I96I) 55 American Journal of International Law 548.

87. American Law Institute, Restatement of the Law (Third) of Foreign Relations Law of the United States (1987), at para. 7 I2, comment (g). 
The tribunal, drawing support from the Organization for Economic Co-operation and Development's [OECD] paper on indirect expropriation, ${ }^{88}$ laid down the police powers rule in CIL as follows: "State's reasonable bona fide exercise of police powers in such matters as the maintenance of public order, health or morality, excludes compensation even when it causes economic damage to an investor and that measures taken for that purpose should not be considered expropriatory." 89 The tribunal further justified the police powers rule by citing past ISDS tribunals that made mention of it, ${ }^{\circ}$ and from the fact that the rule "has found confirmation in recent trade and investment treaties" such as the 20I 2 US Model BIT ${ }^{91}$ and the EU-Canada Comprehensive Economic and Trade Agreement [CETA]. ${ }^{92}$ On this basis, the tribunal concluded that, irrespective of whether the police powers rule is introduced in the treaty, it reflects the position under general international law, ${ }^{93}$ i.e. it is significant in interpreting Article 5(I).

After reaching this conclusion, the tribunal devoted the next three paragraphs to examining whether the SPR and the $80 / 80$ Regulation were adopted by Uruguay in fulfilment of its national and international legal obligations. ${ }^{94}$ The tribunal referred to Uruguay's domestic law provisions that imposed an obligation on Uruguay to adopt measures for the fulfilment of public health objectives. ${ }^{95}$ The tribunal also referred to international legal instruments like the Framework Convention on Tobacco Control [FCTC] and held that, since the SPR and 80/80 Regulation specifically concerned regulating the use of tobacco, they were in accordance with the FCTC. ${ }^{96}$

In the next paragraph, the tribunal returned to the police powers doctrine, though this time it was stated differently from that in paragraph 295. The tribunal stated that a state's exercise of regulatory powers does not constitute indirect expropriation if such action is bona fide for the purpose of protecting public welfare, is non-discriminatory, and is proportionate. ${ }^{97}$ The tribunal concluded that Uruguay's regulatory measures were proportionate to the objective "they meant to achieve, quite apart from their limited adverse impact on Abal's business"..$^{98}$ In footnote 405 , the tribunal explained that Uruguay's regulatory measures had a limited impact on Abal's investment because it merely limited the use of Abal's trademark, unlike other cases where public health regulatory measures resulted in the banning of the production and

88. OECD, "Indirect Expropriation and the Right to Regulate in International Investment Law", OECD Working Papers on International Investment, 2004/4 September 2004.

89. Philip Morris $v$. Uruguay, supra note 8 at para. 295.

90. The tribunal referred to Tecmed v. Mexico, Saluka v. Czech Republic, Chemtura v. Canada. See Philip Morris $v$. Uruguay, supra note 8 at paras. 295-9.

9I. 20I 2 U.S. Model Bilateral Investment Treaty, art. 6 (3 September 20I7), online: USTR < https://ustr.gov/ sites/default/files/BIT\% 2otext \% 2 ofor\% 20 ACIEP\% 20Meeting.pdf $>$.

92. Comprehensive Economic and Trade Agreement [CETA)] Between Canada and the European Union, art. 8.I2 (4 September 20I7), online: < https://trade.ec.europa.eu/doclib/docs/20I4/september/tra doc_I $52806 . p d f>$.

93. Philip Morris $v$. Uruguay, supra note 8 at para. $30 \mathrm{I}$.

94. Ibid., paras. $302-4$.

95. Ibid.

96. Ibid., para. 304 .

97. Ibid., para. 305 .

98. Ibid., para. 306. 
sale of the subject matter. ${ }^{99}$ On this basis, the tribunal thereby concluded that the challenged measures were a valid exercise of Uruguay's police powers for the protection of public health, and thus did not constitute an expropriation of the claimant's investment. $^{\text {Io० }}$

Now let us evaluate the tribunal's analysis on each of the four components of Article $3 \mathrm{I}(3)(\mathrm{c})$ mentioned before.

\section{B. Did the Tribunal Precisely Identify the "Rule"?}

"[R]ules of international law" in Article $3 \mathrm{I}(3)(\mathrm{c})$ refers to rules that can be derived from CIL, treaties, and the general principles of law. Inherent in this derivation is the fact that the rule(s) should be precisely identified. The rule in question here is the police powers rule. It is one thing to say that the police powers rule is part of CIL, quite another to precisely lay down the rule. The Philip Morris tribunal dealt with the police powers rule in two instances. First, in paragraph 295, the tribunal laid down the police powers rule in CIL as follows: reasonable bona fide regulatory measures adopted by a state for the purpose of public welfare such as public health does not constitute expropriation, and thus absolves the state from paying compensation to the foreign investor, notwithstanding the economic damage caused to the investor (Rule I). In other words, as Newcombe and Paradell have argued, according to Rule I, a legitimate and bona fide exercise of the state's police powers does not amount to indirect expropriation, subject inter alia to an analysis of reasonableness. ${ }^{\text {IOI }}$ Second, in paragraphs 305 and 306, the tribunal introduced the notion of "proportionality" and defined the police powers rule as follows: a bona fide, non-discriminatory regulatory measure adopted for public welfare does not amount to indirect expropriation, provided the regulatory measure is proportionate (Rule 2 ).

Is Rule I the same as Rule 2? If the answer is "yes", one can say that the Philip Morris tribunal identified the police powers rule precisely. If the answer is "no", the tribunal did not lay down the police powers rule precisely. Let us examine this.

The core distinction between Rule I and Rule 2 is that, while the former talks of the test of reasonableness, the latter talks of the test of proportionality. Is the test of reasonableness different from test of proportionality? While a full analysis of the tests of reasonableness ${ }^{\mathrm{IO} 2}$ and proportionality ${ }^{\mathrm{IO} 3}$ is beyond the scope of this paper, it will be useful to briefly discuss how ISDS tribunals have dealt with these terms. While some

\footnotetext{
99. Methanex, supra note 5 at para. 298; Chemtura, supra note 69 at para. 299.

Ioo. Philip Morris v. Uruguay, supra note 8 at paras. $306,307$.

IOI. Newcombe and Paradell, supra note 40 at 358 .

I02. For a discussion on the test of reasonableness in international law. see Olivier CORTEN, "The Notion of 'Reasonable' in International Law: Legal Discourse, Reason and Contradictions” (I999) 48 International and Comparative Law Quarterly 6I3. For a detailed discussion on the test of reasonableness in international investment law, see Federico ORTINO, "Investment Treaties, Sustainable Development and Reasonableness Review: A Case against Strict Proportionality Balancing” (2017) 30 Leiden Journal of International Law $7 \mathrm{I}$.

I03. On the issue of proportionality, see Benedict KINGSBURY and Stephan SCHILL, "Public Law Concepts to Balance Investors' Rights with State Regulatory Actions in the Public Interest-The Concept of Proportionality" in Stephan SCHILL, ed., International Investment Law and Comparative Public Law (New York: Oxford University Press, 2010) 75; Sweet, supra note 42.
} 
ISDS tribunals refer to reasonableness without defining the nature of their review, ${ }^{\mathrm{IO}}$ some say that a measure will be reasonable if there is an "appropriate correlation between the State's public policy objective and the measure adopted to achieve it". ${ }^{\text {I05 }}$ Some even go one step further and say that, in addition to an appropriate correlation existing between the public policy objective and the measure adopted, the measure's impact on the investor should be proportionate to the policy objective sought. ${ }^{\text {I06 }}$ In other words, the meaning of the word "reasonable" could vary from a measure making a (significant) contribution to the public policy objective to a more strict interpretation involving weighing and balancing the impact of the measure on foreign investment with the public policy it seeks to achieve. ${ }^{\text {I07 }}$ The strict interpretation of "reasonable" has the same meaning as "proportionality", which consists of three steps ${ }^{\text {I08 }}$ that must be assessed cumulatively. ${ }^{\text {I09 }}$ First, whether the measure is suitable for the legitimate public purpose-this requires a causal link between the measure and its object. ${ }^{\text {IIO }}$ If the first step is fulfilled, the second step asks whether the measure is necessary, i.e. whether there is a less restrictive alternative measure that will achieve the same objective. ${ }^{\text {III }}$ If the measure is found to be "necessary", the third step (also known as proportionality stricto sensu) will involve balancing the effects of the measure on the right that has been affected with the public benefit the measure seeks to achieve. ${ }^{\text {II } 2}$

The Philips Morris tribunal did not explain the meaning of "reasonable" under Rule I and "proportional" under Rule 2. If the tribunal intended the stricter interpretation of "reasonable" as laid down in Eletrabel $v$. Hungary, one can conclude that Rule I and Rule 2 laid down the same police powers rule. However, since the tribunal did not give much indication about this, it is plausible to conclude that the words "reasonable" and "proportional" do not have the same meaning, i.e. "reasonable" under Rule I has a broader meaning than "proportional". In fact, the tribunal commented that the impugned regulatory measures were directed at and capable of achieving the regulatory objective of reducing instances of smoking, ${ }^{\mathrm{II} 3}$ which seems to point to the broader meaning of "reasonable". If we accept the broader meaning of "reasonable",

I04. Pope and Talbot v. Canada, Ad hoc Tribunal (UNCITRAL), Award on the Merits of Phase 2, Io April 200I, at paras. I23, I25.

I05. AES Summit Generation Limited and AES-Tisza Erömü Kft v. The Republic of Hungary, ICSID Case No $\mathrm{ARB} / 07 / 22$, Award of 23 September 2010, at para. I0.3.9. Also see Saluka Investments B.V. (The Netherlands) v. The Czech Republic, UNCITRAL (Partial Award) (I7 March 2006) at para. 309 [Saluka Partial Award].

I06. Electrabel S.A. v. Republic of Hungary, ICSID Case No. ARB/o7/19, Award, I 5 November 2015, at para. I79. Also see Micula et al v. Romania, Award, I I December 2013, at para. 525.

I07. Ortino, supra note I02 at $72-3$.

I08. HAN Xiuli, "The Application of the Principle of Proportionality in Tecmed v. Mexico" (2007) 6 Chinese Journal of International Law 635 at 636-7; Kingsbury and Schill, supra note 103 at 85-8; Andreas KULICK, Global Public Interest in International Investment Law (Cambridge: Cambridge University Press, 20I2) at I86-9.

I09. Erlend M. LEONHARDSEN, "Looking for Legitimacy: Exploring Proportionality Analysis in Investment Treaty Arbitration" (2OI I) 3 Journal of International Dispute Settlement 95; Jan H. JANS, "Proportionality Revisited" (2000) 27 Legal Issues of Economic Integration 239 at 240-I.

I Iо. Ibid. See also Jans, supra note Io9 at 240.

II I. Jans, supra note IO9 at 240; Kingsbury and Schill, supra note I03 at 86-7.

I I2. Jans, supra note Io at, 24I; Kingsbury and Schill, supra note 99 at 87-8.

II3. Philip Morris v. Uruguay, supra note 8 at para. 306. 
Rule I can be elaborated as follows: bona fide and non-discriminatory measures adopted by a state for the purpose of public welfare, such as public health, does not constitute expropriation if the measure has a rational relationship with the public policy goal it seeks to achieve, and thus absolves the state from paying compensation to the foreign investor, notwithstanding the economic damage caused to investment. Consequently, Rule 2 can also be elaborated as follows: a bona fide, nondiscriminatory regulatory measure adopted for public welfare does not amount to indirect expropriation, provided the regulatory measure is proportionate, i.e. the measure is suitable for the regulatory goal, is necessary, and balances the effects with the benefits that it seeks to achieve. When the notion of proportionality is brought in, it means there is an admission of the fact that bona fide non-discriminatory regulatory measures adopted for public welfare (such as public health) could amount to expropriation if the effect of the regulatory measure on foreign investment is disproportionate to the benefits of the measures.

Laying down two different conceptions of the police powers rule and the failure to identify the police powers rule precisely show a lack of internal consistency in the tribunal's reasoning. The fact that the Philip Morris tribunal failed to identify the police powers rule precisely ${ }^{\mathrm{I} 4}$ is buttressed when we undertake a close study of the different ISDS tribunals that it cited to support the police powers doctrine. ${ }^{\text {II } 5}$ The tribunal cited Methanex v. USA, Saluka v. Czech Republic, Tecmed v. Mexico, and Chemtura $v$. Canada. The choice of cases cited by the tribunal is interesting. It gives an impression that all these cases laid down a common police powers rule. While it is true that all these tribunals recognized the police powers doctrine in claims of indirect expropriation, it is misleading to present them as if there were no differences in the manner in which these tribunals laid down the police powers rule. These differences, if ignored, could result in conceptual errors. Let us briefly discuss the police powers rule laid down by each tribunal. Since these cases have already been discussed in detail in the literature, we will focus only on the parts relevant to laying down the police powers rule.

\section{Methanex $v$. USA (or the Methanex rule)}

Methanex $v$. USA, the oft-cited case whenever any tribunal talks of the police powers rule, laid down the rule as follows:

[A]s a matter of general international law, a non-discriminatory regulation for a public purpose, which is enacted in accordance with due process and, which affects, inter alios, a

II4. Also see Radi, supra note I9.

I I 5. Although it is well established that the doctrine of binding precedent does not apply in international adjudication (see AES Corporation v. The Argentine Republic, ICSID Case No. ARB/o2/I7, Decision on Jurisdiction, 26 April 2005, at para. 23), ISDS tribunals do refer to previous decisions for inspiration or guidance (see AES Corporation v. The Argentine Republic at para. 30, Saipem S.p.A. v. The People's Republic of Bangladesh, ICSID Case No. ARB/05/07, Decision on Jurisdiction and Recommendation on Provisional Measures, 2I March 2007, at para. 67). 
foreign investor or investment is not deemed expropriatory and compensable unless specific commitments had been given by the regulating government to the then putative foreign investor contemplating investment that the government would refrain from such regulation. ${ }^{116}$

According to the Methanex tribunal, the primary test for determining whether a measure amounts to expropriation or lawful, non-compensable regulations depends on whether it is taken for a public purpose in a non-discriminatory manner, through a law enacted with due process. There can only be indirect expropriation if the state reneges on specific commitments given to the investor that it would refrain from adopting a regulatory measure. There is neither a mention of regulatory measures being "reasonable" or "proportional". Thus, it is different from both Rule I and Rule 2 laid down by the Philip Morris tribunal. There are other noticeable differences. First, Rule I specifically includes "economic damage" in the police powers rule, which is missing in the Methanex rule. Second, Rule I does not include "specific commitments" as part of the police powers rule, which is present in the Methanex rule. Another important issue not specifically captured in the rule laid down by the Methanex tribunal is the role of the quantum of economic harm caused to foreign investment as a factor to determine indirect expropriation. ${ }^{\mathrm{II} 7}$ Thus, the critical question is: assuming that a regulatory measure satisfies all the above conditions but results in the total or substantial deprivation of foreign investment, will it still be non-compensable? The Saluka and the Chemtura cases discussed in the following sections dealt with this issue.

\section{Saluka v. Czech Republic (or the Saluka rule)}

In this case, the tribunal had to interpret the expropriation provision in Article 5 of the Czech Republic-Netherlands BIT (I99I) titled “deprivation". The tribunal, citing Article $3 \mathrm{I}(3)(\mathrm{c})$, held that the term "deprivation" given in Article 5 imports into the BIT the CIL notion that the exercise of regulatory actions aimed at maintaining public order justify deprivation. ${ }^{\text {II } 8}$ The tribunal went on to lay down the police powers rule as follows: It is now established in international law that states are not liable to pay compensation to a foreign investor when, in the normal exercise of their regulatory powers, they adopt bona fide regulations that are aimed at general welfare in a nondiscriminatory manner. The tribunal then held that regulatory measures falling under the police powers doctrine do not constitute expropriation, notwithstanding the fact that "the measure had the effect of eviscerating" foreign investment. ${ }^{\text {II }}$ If evisceration is to be understood as "substantial deprivation" of foreign investment, the rule can be expressed as follows: states are not liable to pay compensation to a foreign investor when, in the normal exercise of their regulatory powers, they adopt non-discriminatory, bona fide regulations aimed at general welfare, notwithstanding the

\footnotetext{
I 16. Methanex, supra note 5, Award, Part IV, Ch D, 4 at para. 7.

I 17. Kurtz, supra note 29 at 292.

I 8. Saluka v. Czech Republic, supra note 4I, para. 254.

II9. Ibid., para. 276. Also see para. 262.
} 
quantum of harm such measures might cause to foreign investment. ${ }^{20}$ Although the tribunal did mention that the police powers exception is not absolute, ${ }^{\mathrm{I} 2 \mathrm{I}}$ it defined the boundary of the police powers exception only in terms of the measure not being discriminatory and being bona fide (i.e. adopted for a rational public objective). There is no mention, at least not clearly, of the measure being either reasonable or proportionate. Thus, the Saluka rule differs from both the rules laid down by the Philip Morris tribunal. The Saluka rule also does not talk of "specific commitments" mentioned in the Methanex rule, and thus differs from the Methanex rule as well. The Saluka rule can be articulated as follows: a bona fide, non-discriminatory measure adopted for public welfare objective is not expropriatory, notwithstanding the economic impact on foreign investment. ${ }^{\text {I22 }}$

\section{Chemtura v. Canada (or the Chemtura rule)}

In Chemtura $v$. Canada, ${ }^{I 23}$ the ban imposed by the Canadian Pesticide Management Regulation Agency [PMRA] on "lindane", a pesticide used in canola farming and considered to have an adverse effect on human health, was challenged by the claimant, Chemtura, a US company manufacturing "lindane", as amounting to expropriation under Article I I Io of the North American Free Trade Agreement [NAFTA]. The tribunal laid down the police powers rule as follows:

Irrespective of the existence of a contractual deprivation, the Tribunal considers in any event that the measures challenged by the Claimant constituted a valid exercise of the Respondent's police powers ... [The measures were adopted] in a non-discriminatory manner, motivated by the increasing awareness of the dangers presented by lindane for human health and the environment. A measure adopted under such circumstances is a valid exercise of the State's police powers and, as a result, does not constitute an expropriation. ${ }^{24}$

The Chemtura rule comes close to Rule I laid down by the Philip Morris tribunal. It talks of deprivation, which presumably is the same as economic damage mentioned in Rule I. It also imposes a requirement that measures be non-discriminatory, as is the case with measures in Rule I. Furthermore, stating that the measures adopted were

I20. In this regard, also see Burlington Resources Inc. $v$. Republic of Ecuador, ICSID Case No ARB/o8/5,

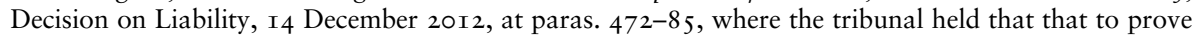
whether a regulatory measure amounts to indirect expropriation, it has to be shown that the regulatory measures (i) resulted in substantial deprivation of investment, (ii) on a permanent basis, and (iii) has no justification in the police powers doctrine.

I2I. Saluka v. Czech Republic, supra note 4I at paras. 257, 258.

I22. It is interesting to compare the Saluka rule with the tribunal's holding in Seuz v. Argentina, 30 July 2010 - the tribunal in para. 139 laid down the police power rule as follows: "in evaluating a claim of expropriation it is important to recognize a State's legitimate right to regulate and to exercise its police power in the interests of public welfare and not to confuse measures of that nature with expropriation." In the very next paragraph, the tribunal held that "given the nature of the severe crisis facing the country, those general measures were within the general police powers of the Argentine State, and they did not constitute a permanent and substantial deprivation of the Claimants' investments". In other words, the tribunal seemed to suggest that a legitimate measure adopted by a state for public welfare (the police power exception) can be expropriatory if it constitutes a permanent and substantial deprivation of foreign investment. So, notwithstanding the police power rule, the determining factor to establish indirect expropriation is substantial deprivation.

I23. Chemtura, supra note 69 at para. 266

I24. Ibid., para. 266. 
motivated by increasing health risks is tantamount to stating that the measures were reasonable (made a contribution to the public policy objective) as given in Rule I, but not in the Saluka rule. However, the Chemtura rule is not the same as Rule 2, laid down by the Philip Morris tribunal, because it does not talk of measures being proportional.

4. Tecmed v. Mexico (or the Tecmed rule)

Another case cited by the Philip Morris tribunal in support of the police powers rule is Tecmed $v$. Mexico. The tribunal cited paragraph I I9 ${ }^{\mathrm{I25}}$ of Tecmed $v$. Mexico: "The principle that the State's exercise of its sovereign power within the framework of its police powers may cause economic damage to those subject to its powers as administrator without entitling them to any compensation whatsoever is undisputable." ${ }^{26}$ However, the tribunal's analysis did not end here, and thus by merely quoting the above statement, the Philip Morris tribunal could be accused of selective reading of Tecmed $v$. Mexico. The tribunal in Tecmed $v$. Mexico went on to state that

we find no principle stating that regulatory administrative actions are per se excluded from the scope of the Agreement [Spain-Mexico BIT ${ }^{\mathrm{I} 27}$ ], even if they are beneficial to the society as a whole-such as environmental protection-particularly if the negative economic impact of such actions on the financial position of the investor is sufficient to neutralize in full the value, or economic or commercial use of its investment without receiving any compensation whatsoever. ${ }^{\mathrm{I2} 8}$

In other words, there is a clear recognition that regulatory measures that fall within the police powers of the state may nevertheless be expropriatory if the impact of such measures on foreign investment effectively neutralizes the value of investment. Finally, the tribunal, by taking into account both the purpose behind the regulatory measure and the effect on foreign investment, stated that in order to determine if a regulatory measure is expropriatory or not, one needs to find out "whether such actions or measures are proportional to the public interest presumably protected thereby and to the protection legally granted to investments, taking into account that the significance of such impact has a key role upon deciding the proportionality". ${ }^{29} 9$ Thus, according to the tribunal, a regulatory measure shall not be expropriatory if a "reasonable relationship of proportionality" could be established between the charge or weight imposed by the measure on foreign investment and the aim that the impugned measure seeks to achieve. ${ }^{\mathrm{I}}{ }^{\circ}$

This articulation of the police powers rule, requiring a reasonable relationship of proportionality, comes close to Rule 2 given by the Philip Morris tribunal, but is very different from the Methanex, Saluka, and Chemtura rules. In sum, one can safely

\footnotetext{
I25. Philip Morris v. Uruguay, supra note 8 at para. 296.

I26. Tecmed Award, supra note 42 at para. I I9.

I27. Acuerdo Para La Promocion Y Proteccion Reciproca De Inversiones Entre El Reino De España Y Los Estados Unidos Mexicanos, Io October 2006.

I28. Tecmed Award, supra note 42 at para. I2I.

I29. Ibid., para. I22.

I30. Ibid. For a critical take on Tecmed's proportionality analysis, see Henckels, supra note 42 at 232. Also see Leonhardsen, supra note Io9.
} 
conclude that the Philip Morris tribunal did not identify the police powers rule precisely. The four cases it cited in support of the police powers rule, while having common elements, differ quite a bit from each other, and thus amounted to a clear misuse of precedent, ${ }^{\mathrm{I}{ }^{\mathrm{I}}}$ one of the reasons for inconsistent and badly reasoned ISDS awards.

\section{Is the Rule Applicable in the Relations Between the Parties?}

The rule of international law identified should be "applicable in the relations between the parties", ${ }^{132}$ unless one of the states has persistently objected to the rule. ${ }^{133}$ Whether a rule of international law is "applicable" between the parties to the treaty is composed of many facets, such as how to address the issue of inter-temporal law in question (i.e. whether the applicability is to be restricted to those rules that were in force when the treaty in question was concluded ${ }^{\mathrm{I} 34}$ or those that have evolved up to the time of interpretation of the treaty ${ }^{\mathrm{I} 5}$ ), and whether "applicable" is restricted to rules that are "binding" or "in force" between the parties or whether the term "applicable" should be interpreted more flexibly such that it goes beyond the strict meaning of "in force" or "binding". ${ }^{\text {136 }}$

Answering these questions is beyond the scope of this paper, and has in fact been dealt with elsewhere. ${ }^{\mathrm{I} 7}$ It is, however, sufficient to say that since the police powers rule, notwithstanding the lack of consistency in defining it, owes its origins to CIL, it is binding on all countries, and therefore is clearly "applicable" "in relations between the parties" to the treaty as mandated by Article $3 \mathrm{I}(3)(\mathrm{c})$.

Another doctrinal question is what is the meaning of "parties" in Article $3 \mathrm{I}(3)(\mathrm{c})$ does it refer to parties to the dispute (i.e. rule is only applicable on parties to the dispute) or some/all parties to the treaty being interpreted (i.e. rule is applicable on some/all countries that are parties to the treaty)? This issue has been adequately

I3I. On the issue of ISDS tribunals misusing precedents, see generally Federico ORTINO, "Legal Reasoning of International Investment Tribunals: A Typology of Egregious Failures” (20I2) 3 Journal of International Dispute Settlement 3 I at 38-43; Jeffery P. COMMISSION, "Precedent in Investment Treaty Arbitration: A Citation Analysis of Developing Jurisprudence" (2007) 24 Journal of International Arbitration I 29 at I 56; Zachary DOUGLAS, "Nothing if not Critical for Investment Treaty Arbitration" (2006) 22 Arbitration International 27 at 28 .

I32. See G. ABI SAAB, "The Appellate Body and Treaty Interpretation" in Giorgio SACERDOTI, Alan YANOVICH, and Jan BOHANES (eds.), The WTO at Ten: The Contribution of the Dispute Settlement System (Cambridge: Cambridge University Press, 2006), 463.

133. See Anglo-Norwegian Fisheries Case, [195 I] I.C.J. Rep. I 6 at I3 I; North Sea Continental Shelf Case, [I969] I.C.J. Rep. 3 at 26-7.

I34. See Gerald FITZMAURICE, "The Law and Procedure of the International Court of Justice: General Principles and Sources of Law" (I953) 30 British Yearbook of International Law I at 5 .

135. See Legal Consequences for States of the Continued Presence of South Africa in Namibia (South West Africa) Notwithstanding Security Council Resolution 276 (I970), Advisory Opinion, [I97I] I.C.J. Rep. I6; Gabčikovo-Nagymaros Project (Hungary v. Slovakia), Judgment, 25 September I997, Separate Opinion of Judge Weeramantry, [1997] I.C.J. Rep. 7 at II3-I4; Ulf LINDERFALK, On the Interpretation of Treaties: The Modern International Law as Expressed in the I969 Vienna Convention on the Law of Treaties (Dordrecht: Springer, 2007) at I 82-3.

136. See Simma and Kill, supra note 45 at 697-8, Gardiner, supra note 47 at 264.

I37. Simma and Kill, supra note 45 at 696-7; Gardiner, supra note 47. 
debated, and is thus not dealt with in this paper. ${ }^{138}$ It is sufficient to say that since the Switzerland-Uruguay BIT is a bilateral treaty, the issue is irrelevant in the current case.

The Philip Morris tribunal did not discuss the issue of the applicability of the police powers rule between Uruguay and Switzerland. It presumed that the rule was applicable. However, once a tribunal invokes Article $3 \mathrm{I}(3)$ (c), it is incumbent on the tribunal to deal with all of the major elements of the said provision to ensure that the method of treaty interpretation is robust.

\section{Is the Rule "Relevant"?}

Is the police powers rule "relevant" under Article $3 \mathrm{I}(3)(\mathrm{c})$ ? The question of relevance of a "rule of international law" can be approached in two ways. ${ }^{\text {I39 }}$ The first approach is a narrow one, where the determination of whether a rule is "relevant" is made by "examining criteria such as the subject of the dispute and the content (i.e. the subject matter) of the rules under consideration". ${ }^{40}$ The second approach is a broader one, where "relevant" has a wider meaning and is not restricted to the subject matter of the rule under consideration. ${ }^{\mathrm{I}} \mathrm{I}_{\mathrm{I}}$ Those who argue in favour of the second approach contend that, since Article 30 of the VCLT deals with "successive treaties relating to the same subject-matter", the word "relevant" in Article $3 \mathrm{I}(3)(\mathrm{c})$ "should not be interpreted as requiring unity of subject-matter" ${ }^{\mathrm{I}}{ }^{42}$ In other words, under the broader approach, any rule of international law will be a "relevant" rule, ${ }^{\mathrm{I} 43}$ although bringing in the chapeau of Article $3 \mathrm{I}(3)$ (c), which requires the "relevant" rule to be taken into account together with the "the context" of the treaty, could narrow the broader interpretation of the word "relevant". ${ }^{\text {I44 }}$

With regard to the police powers rule, even if we include both Rule I and Rule 2 given by the Philip Morris tribunal, it will pass the test of "relevant" even under the narrower approach because of the similarity in terms of subject matter. Moreover, under the broader approach, it is surely also a "relevant" rule applicable in the relations between Switzerland and Uruguay. However, as with the issue of "applicable", the tribunal did not discuss the issue of relevance while invoking Article 3 I (3)(c) of the VCLT when considering the police powers rule.

I38. See McLachlan, supra note 48 at 3I4; Gardiner, supra note 47 at 263-75; ILC Anti-Fragmentation Report, supra note 46; Ulf LINDERFALK, "Who Are 'The Parties'? Article 3I, Paragraph $3(\mathrm{C})$ of the I 969 Vienna Convention and the 'Principle of Systemic Integration' Revisited" (2008) 55 Netherland International Law Review 343; Pauwelyn, supra note 46 at 26I; Samson, supra note 48 at 70 I.

I39. Paparinskis, supra note $5 \mathrm{I}$ at $7 \mathrm{I}$.

I40. Gabrielle MARCEAU, "Conflicts of Norms and Conflict of Jurisdictions: The Relationship Between the WTO Agreement and MEAs and Other Treaties" (200I) 35 Journal of World Trade I08 I at I087. Also see Oil Platforms (Iran v. USA), Merits, Judgment, 6 November 2003, Separate Opinion of Judge Higgins, [2003] I.C.J. Rep. I6I at 237, paras. 45-6 [Oil Platforms].

I4I. Simma and Kill, supra note 45 at 695-6. Also see Certain Questions of Mutual Assistance in Criminal Matters (Djibouti v. France), Judgment, 4 June 2008, [2008] I.C.J. Rep. I77 at para II3; Paparinskis, supra note $5 \mathrm{I}$ at $7 \mathrm{I}$; McLachlan, supra note 48 at 280.

I42. Simma and Kill, supra note 45 at 695 . Also see D. FRENCH, "Treaty Interpretation and the Incorporation of Extraneous Legal Rules" (2006) 55 International and Comparative Law Quarterly 28I at 304 .

I43. Simma and Kill, supra note 45 at 696 .

I44. Paparinskis, supra note 5I at 7I; Frank BERMAN, “Treaty 'Interpretation' in a Judicial Context” (2004) 29 Yale Journal of International Law 3 I 5 at 320; Oil Platforms, Separate Opinion of Judge Higgins, supra note I4O at para. 46 . 
On the basis of the above discussion, one can conclude that the police powers rule satisfies the three limbs of paragraph (c). We now turn to the chapeau of Article $3 \mathrm{I}(3)(\mathrm{c})$.

\section{E. The Chapeau of Article 3I(3)(c)}

The chapeau of Article $3 \mathrm{I}(3)$ ensures that international rules admitted as interpretative materials, relying upon paragraph (c), are "taken into account" "together with the context" in interpreting the treaty in question. The significance of the word "context" in Article $3 \mathrm{I}(3)(\mathrm{c})$ was highlighted by Judge Higgins in her separate opinion in the Oil Platforms case, where she said that, while considering relevant rules, one cannot “ignore that Article 3 I, paragraph 3, requires 'the context' [of the treaty] to be taken into account". ${ }^{\mathrm{I} 5}$ Keeping the context in mind, the rule so admitted will have to be given an appropriate interpretative weight. ${ }^{\mathrm{I}}{ }^{6}$ In other words, it is one thing to state that a rule of CIL is a relevant rule applicable in the relations between the parties, and it is quite another to decide what bearing it will have on the treaty provision that is being interpreted. Given the analytical structure of Article $3 \mathrm{I}(3)(\mathrm{c})$, one should be mindful of the distinction between using relevant rules to interpret the treaty and applying the same rules directly to the facts at hand, resulting in the displacement of the applicable law. ${ }^{\mathrm{I}} 7 \mathrm{The}$ "rule" found admissible in the treaty interpretative process should be used to clarify the content of the provision being interpreted, and not to limit the treaty provision to the scope and content of the admissible rule. ${ }^{\mathrm{I} 48}$

The Philip Morris tribunal did not take the police powers rule into account together with the context of the Switzerland-Uruguay BIT in interpreting Article 5(I) of the treaty. There is no discussion of what interpretative weight was attached to the police powers rule or how the police powers rule assisted the tribunal in finding the meaning of the expropriation provision in Article 5(I). The tribunal merely cited Article $3 \mathrm{I}(3)$ (c), before directly applying the police powers rule to the facts at hand by judging the consistency of the SPR and the $80 / 80$ Regulation with the police powers rule. ${ }^{\text {I4 }}$ The tribunal concluded that, since these regulations meet the police powers rule, they are not expropriatory. The tribunal missed the critical distinction between the admissibility of an extraneous rule as treaty interpretative material and the interpretative weight that is to be attached to this interpretative material. ${ }^{150}$ This represents a classic

\footnotetext{
I45. Oil Platforms, Separate Opinion of Judge Higgins, supra note I 40 at para. 46.

I46. Paparinskis, supra note 5 I at 73 .

I47. Gardiner, supra note 47 at 278 ; Berman, supra note I 44 at 620.

148. Alexander ORAKHELASHVILI, "Restrictive Interpretation of Human Rights Treaties in the Recent Jurisprudence of the European Court of Human Rights" (2003) I4 European Journal of International Law 537; Kurtz, supra note 29 at 28 I observes that "the distinction in the use of external normsbetween direct applicability and interpretative guidance-is sometimes elided". Also see French, supra note I45 at 288-90. Also see Philippe SANDS, "Treaty, Custom and the Cross-fertilisation of International Law" (I998) Io Yale Human Rights and Development Law Journal 3 at 8; Pauwelyn, supra note 46 at $253-4$.

I49. Philip Morris v. Uruguay, supra note 8 at paras. 305-7.

I50. Also see Paparinskis, supra note $5 \mathrm{I}$.
} 
example of the minimalism that Ortino has rightly identified as one of the egregious failures of reasoning by ISDS tribunals.

The approach of the tribunal reduces Article $3 \mathrm{I}(3)(\mathrm{c})$ to a mere licence to incorporate an extraneous rule into the treaty and apply it directly to the facts at hand, rather than contextualizing it according to the treaty. In fact, while discussing the police powers rule, the tribunal did not refer to the expropriation provision in the BIT at all. ${ }^{\mathrm{I} 5 \mathrm{I}}$ Consequently, the tribunal erringly ended up displacing Article 5(I) - the very provision it was mandated to interpret-due to its reliance on the CIL police powers rule.

The approach of the Philip Morris tribunal in using Article $3 \mathrm{I}(3)(\mathrm{c})$ is not very different from the approach the International Court of Justice [ICJ] adopted in the Oil Platforms case. ${ }^{152}$ This case involved the destruction of Iranian oil platforms by the US, at the time of Iran-Iraq war when the US was defending its shipping in the Gulf. ${ }^{153}$ Iran alleged that the US, inter alia, had violated Article X(I) of the 1955 Treaty of Amity, Economic Relations and Consular Rights between the US and $\operatorname{Iran}^{154}$ that provides for freedom of commerce. ${ }^{\mathrm{I} 5}$ The ICJ found that Article XX (I)(d) ${ }^{156}$ of the I955 treaty does not preclude the Contracting Parties from adopting "measures ... necessary to protect its essential security interests", as providing the parties a possible defence on the merits. ${ }^{157}$ At the time of considering the merits, the majority judgment took the general international law defence of self-defence as the starting point by making reference to Article $3 \mathrm{I}(3)$ (c) of the VCLT. ${ }^{158}$ This approach meant that the Court, as Judge Higgins in her separate opinion said, did not interpret Article XX(I)(d) of the 1955 treaty using treaty interpretation rules, but invoked Article $3 \mathrm{I}(3)$ (c) to displace Article $\mathrm{XX}(\mathrm{I})(\mathrm{d})$ (the applicable law) with CIL on the use of force. ${ }^{\text {I } 59}$

The Saluka tribunal made a similar conceptual error. As mentioned before, the mandated task of the tribunal was to interpret the term "deprivation", which provided the provision on expropriation. The tribunal invoked CIL on expropriation using Article $3 \mathrm{I}(3)(\mathrm{c})$ and thereby brought in the police powers rule. ${ }^{160}$ It then, just as the Philip Morris tribunal did, directly applied the police powers rule, although the mandate of the tribunal was to interpret and apply Article 5 of the Netherland-Czech Republic BIT. Through the direct application of the police powers rule, which led to the displacement of the applicable law, the tribunal concluded that the state had not expropriated foreign investment, i.e. had not violated Article 5 of the BIT. ${ }^{\text {6I }}$

\footnotetext{
I 5 I. Philip Morris v. Uruguay, supra note 8 at paras. 290-307

I 52. Oil Platforms, supra note I40.

I 53. Gardiner, supra note 47 at 278.

I 54. Treaty of Amity, Economic Relations and Consular Rights between the United States and Iran, I 5 August I955, 284 U.N.T.S. 93 (entered into force I6 June 1957) [Iran-U.S. Treaty of Amity].

I 5. Oil Platforms, supra note $\mathrm{I} 40$ at para. I 8 (b).

I 56. Iran-U.S. Treaty of Amity, supra note I 54, art. XX(I)(d).

I 57. Oil Platforms (Islamic Republic of Iran v. USA), (Preliminary Objection), [I996-II] I.C.J. Rep. 820 at para. 53.

I 5. Oil Platforms, supra note $\mathrm{I} 40$ at para. $4 \mathrm{I}$.

I 59. Oil Platforms, Separate Opinion of Judge Higgins, supra note I40 at para. 49.

I60. Saluka v. Czech Republic, supra note 4I at para. 254.

I6I. Ibid., at para. 276. Also contrast these treaty interpretation methodologies with the methodology followed by the tribunal in Chevron v. Ecudaor, UNCITRAL, PCA Case No. 2009-23. The tribunal had to
} 


\section{CONCLUSION: WHAT SHOULD THE TRIBUNAL HAVE DONE AND WHAT SHOULD OTHER TRIBUNALS DO IN THE FUTURE?}

From the discussion above, the Philip Morris tribunal's reasoning in using Article 3 I (3) (c) to interpret the expropriation provision in the Switzerland-Uruguay BIT was arguably flawed. The reasoning was internally inconsistent, based on a misuse of arbitral precedents and suffered from minimalism. The Philip Morris tribunal should not have divided its analysis of the expropriation provision into two parts as it is doctrinally and conceptually problematic. Given these errors, the core question is: What should the Philip Morris tribunal have done?

To answer this, let us briefly discuss Article 5(I) of the Switzerland-Uruguay BIT. As mentioned before, Article 5(I) prohibits countries from expropriating foreign investment either directly or indirectly, i.e. taking measures that would have the same effect on foreign investment as direct expropriation, unless the following conditions are met: (I) the investment has been expropriated for public benefit as established by law; (2) the investment has been expropriated on a non-discriminatory basis following due process of law; and (3) effective and adequate compensation is paid.

Thus, to prove that the above-mentioned provision has been breached, two conditions have to be satisfied. First, it must be proved that the state has expropriated foreign investment. Second, this expropriation must have taken place without satisfying the three criteria mentioned above. If the host state expropriates foreign investment, directly or indirectly, satisfying all these three conditions, it would amount to lawful expropriation. Otherwise, it would amount to unlawful expropriation. In Article 5(I), "public benefit" exists as a criterion to determine the legality of expropriation. Article 5(I) does not allow "public benefit" to be used to determine whether expropriation has taken place. ${ }^{\mathrm{I} 62}$ According to Article 5(I), the criterion to determine expropriation is whether the regulatory measure resulted in substantial deprivation of foreign investment. In other words, under Article 5(I) of the Switzerland-Uruguay BIT, borrowing from Paparinskis, "expropriation is only permitted for bonafide regulation if compensation is paid" and not otherwise. ${ }^{163}$ In short, the rule given in Article $5(\mathrm{I})$ is "compensation in all cases", ${ }^{164}$ i.e. even when regulation is non-discriminatory and bona fide aimed at achieving a public purpose, provided it results in substantial deprivation of foreign investment. The criterion to

interpret art. II(7) of the US-Ecuador BIT, which imposes an obligation on the host state "to provide effective means of asserting claims and enforcing rights" to foreign investors. The tribunal held that art. II (7) overlaps significantly with CIL on denial of justice (para. 242). The tribunal then emphasized that its role is to interpret and apply art. II(7), which can be informed by the CIL on denial of justice (para. 244). The tribunal was careful not to state that it could directly apply the CIL on denial of justice, which would have the effect of displacing the treaty norm.

162. See also Siemens A.G. v. The Argentine Republic, ICSID Case No. ARB/o2/8, 6 February 2007, at para. 270, which said that the purpose is a criterion to determine whether expropriation is in accordance with the BIT, not to determine whether expropriation has taken place.

163. Paparinskis, supra note 5 I at 89.

I64. Ibid. 
distinguish legitimate regulation from expropriation is the quantum and degree of deprivation. ${ }^{\text {I65 }}$

While the Philip Morris tribunal clearly identified the above principles and applied them to the facts, its discussion and application of the police powers rule is not convincing. It neither identified the police powers rule clearly nor did it rigorously discuss how the police powers rule satisfied the four components of Article 3 I (3)(c).

In order to complete the argument, let us, borrowing again from Paparinskis, identify the customary police powers rule as follows: "no expropriation for bonafide regulation despite substantial interference with investment" or in other words, "no compensation in some cases". ${ }^{166}$ Now, the question is how this rule will be applied to interpret Article 5(I) of the Switzerland-Uruguay BIT using Article 3 I (3)(c) of the VCLT. It will first have to be established that the rule is a "relevant" rule of international law "applicable in the relations between the parties", and thus admissible as interpretative material under Article $3 \mathrm{I}$ (3)(c) to interpret Article 5(I). The rule that we have identified would pass the three tests of Article $3 \mathrm{I}(3)(\mathrm{c})$, as has been discussed in Section III. The next question is what interpretative weight should be given to this customary rule. The customary rule of "no compensation in some cases" should be compared and contrasted with the treaty norm of "compensation in all cases", and thereafter rejected. ${ }^{167}$ Since the treaty rule, as discussed earlier, does not permit substantial interference with investment without compensation, it cannot be read to allow substantial interference with investment in certain cases (such as when the measure is bona fide and for public purpose) without compensation.

This case is also significant because it raises the larger issue of the relationship between the police powers rule and the expropriation provision in the BIT. It is critical to bear in mind that invoking the police powers rule in assessing expropriation claims would mean relying upon, inter alia, "public welfare", "public benefit", or "public interest" ${ }^{168}$ as the criteria to determine expropriation. This, in turn, could result in a strange contradiction where, despite substantial deprivation of investment, there would not be any expropriation because the regulatory measure would have been adopted to achieve a "public purpose", subject to it being nondiscriminatory and enacted under due process. Such an interpretation would defeat the very purpose of having expropriation provisions like Article 5(I) in the Switzerland-Uruguay BIT. ${ }^{169}$ Indeed, the law of expropriation as codified in numerous BITs clearly recognizes that a nondiscrimnatory measure that deprives the investor of her investment is expropriatory even if enacted under due process to achieve a public benefit. ${ }^{170}$ If presence of public benefit becomes the criterion to distinguish between compensable and non-

\footnotetext{
165. Kurtz, supra note 29 at 29 I.

I66. Ibid.

I67. Ibid.

I68. The phrases "public purpose" and "public interest" have often been used interchangeably. See Siemens $v$. Argentina, ICSID Case No. ARB/o2/8, 6 February 2007, at para. 273; Inmaris Perestroika Sailing Maritime Services GmbH and Others v. Ukraine, ICSID Case No ARB/o8/8, I March 20I2. On this point, also see Yvette ANTHONY, "The Evolution of Indirect Expropriation Clauses: Lessons from Singapore's BITs/FTAs” (2017) 7 Asian Journal of International Law 3 I 9 at 330-2.

169. See Kenneth J. VANDEVELDE, Bilateral Investment Treaties: History, Policy and Interpretation (Oxford: Oxford University Press: 2010) 296.

I70. Radi, supra note I9.
} 
compensable regulation, it would allow host states to shift the burden of achieving public benefit onto foreign investors even for regulatory measures that lead to deprivation of investment. ${ }^{17 \mathrm{I}}$ As it has been argued, "historically, police powers have never been meant to cover regulations amounting to expropriations, except perhaps in situations where there is a state of emergency or a state of necessity". ${ }^{172}$

In other words, it is one thing to state that a host state has the right to adopt nondiscriminatory regulatory measures for a public purpose, and it is another thing to decide how this will be applied in the light of the fact that this very host state has accepted restrictions on its right by entering into a BIT containing the aforementioned expropriation provision. The tribunal in ADC $v$. Hungary ${ }^{173}$ held that, while a sovereign nation possesses the inherent right to regulate its domestic affairs, the exercise of this right must have its boundaries. ${ }^{174}$ The tribunal recognized that the relevant BIT provided such boundaries. ${ }^{175}$ Similarly, the Azurix tribunal found the criterion that the "host state is not liable for economic injury that is the consequence of bonafide regulation within the accepted police powers of the state" was insufficient to determine what constitutes indirect expropriation, and recognized that a legitimate measure serving public purpose could give rise to a compensation claim. ${ }^{176}$

An apprehension often expressed is that focusing solely on the effect of the regulatory measure, not the purpose, to determine indirect expropriation will reduce the regulatory space available to host countries to adopt measures in the public interest. However, this apprehension is lessened if one adopts the "substantial deprivation" test. This test will ensure that an adverse effect on foreign investment will not constitute expropriation, unless that effect results in a "substantial deprivation" of foreign investment. ${ }^{177}$ This high threshold gives the host state ample space to adopt a number of regulatory measures for the public purpose without worrying about expropriation. The analysis of the tribunal on the effect of Uruguay's regulatory measures on Philip Morris's investment is testament to this fact. ${ }^{178}$ As discussed in this paper, the tribunal

I7I. Vandevelde, supra note I69.

I72. F. VICUNA, “Carlos Calvo, Honorary NAFTA Citizen” (2002) I I New York University Environmental Law Journal I9 at 27. See also Mostafa, supra note 38.

173. ADC Affiliate Ltd and ADC and ADMC Management Ltd v. The Republic of Hungary, ICSID Case No. $\mathrm{ARB} /{ }^{3} / \mathrm{I} 6$ (Award 2 October 2006).

I74. Ibid., at paras. 423-4.

I75. Ibid.

176. Azurix, supra note 42 at para. 3 10. See also Anne K. HOFFMAN, "Indirect Expropriation" in August REINISCH, ed., Standards of Investment Protection (New York: Oxford University Press, 2008), I 5 I; Kenneth J. VANDEVELDE, “A Comparison of the 2004 and 1994 U.S. Model BITs: Rebalancing Investor and Host Country Interests" in Karl P. SAUVANT, ed., Yearbook on International Investment Law and Policy (New York: Oxford University Press, 2009), 283 at 302; Kurtz, supra note 29 at 290-I; Fireman's Fund Insurance Company $v$. The United Mexican States, ICSID Case No. ARB(AF)/O2/I, (NAFTA), Award, I7 July 2006, at para. I74; Corn Products International, Inc. v. United Mexican States, ICSID Case No. ARB(AF)/O4/OI, (NAFTA), Decision on Responsibility, I 5 January 2008, at para. 89 .

I77. For example, the tribunal in Sempra Energy $v$. Argentina held that, although Argentina's regulatory measures had "a very adverse effect" on foreign investment, there was no expropriation because the high threshold needed to establish indirect expropriation was not met-at para. 285 . Also see Impregilo S.p.A. v. Argentine Republic, ICSID Case No. ARB/o7/I7, para 270.

I78. See Section II of this paper. 
held that simply because regulatory measures lead to some adverse effect, such as deteriorating profits, this is not sufficient to establish "substantial deprivation".

The Philip Morris tribunal's analysis of the effect of the regulatory measure on investment clearly showed that Uruguay's tobacco regulations did not lead to expropriation. There was no need for the tribunal to engage in a discussion of the police powers rule. The reasoning of the tribunal on Article $3 \mathrm{I}(3)$ (c) of the VCLT to deal with extraneous norms such as the police powers rules raises a number of conceptual questions. This paper has tried to address some of these issues. Future ISDS tribunals should show greater doctrinal clarity in dealing with these complex issues. Such clarity in legal reasoning will go a long way in increasing the legitimacy of the system for all stakeholders, including states and foreign investors. 